\title{
Concerted Induction of $\beta$-Glucanases of Bacillus circulans WL 12 in Response to Various Yeast Glucans
}

\author{
Hirosato Tanaka, Koji Itakura and Kazuya Toda \\ Department of Agricultural Chemistry. Faculty of Agriculture, \\ Niigata University, Nigata-shi, Japan \\ Received November 1, 1977
}

\begin{abstract}
Bacillus circulans WL 12 was grown on cells of six species of yeasts as inducer substrates, and the courses of progress of $\beta$-glucanase production were compared. Also, the iscelectric focusing patterns of $\beta-1,3$ and $\beta-1,6$ glucanases were determined. Conspicuous differences were observed among the isoelectric focusing patterns of the crude enzymes produced with different yeast species as inducer substrates. Lyses of the cell walls of Pyricularia oryzae $P_{2}$ and several species of yeasts by the enzyme systems were compared. The lysis of the cell walls of Debaryomyces hansenii was stronger in the order of the complexity (number of major peaks etc.) of the $\beta-1,3$ glucanases in isoelectric focusing patterns.
\end{abstract}

Bacillus circulans WL 12 produced several $\beta-1,3$ glucanases, ${ }^{\prime \prime}$ and upon induction with three different glucans it produced enzyme systems which had lytic properties considerably different from each other. ${ }^{2}$ We analyzed the activity profiles of $\beta-1,3$ glucanases and found significant differences among them. ${ }^{2}$ In this study, cells of six strains of yeasts were used as inducer substrates. The courses of progress of enzyme production were distinctly different, dependeng upon the substrate used. The isoelectric focusing patterns of $\beta-1,3$ and $\beta-1,6$ glucanases were compared, and conspicuous differences were observed among the enzyme systems. The lytic actions of the enzyme systems against cell walls of several yeasts and $P$. oryzae $\mathrm{P}_{2}$ were compared.

\section{MATERIALS AND METHODS}

Organisms. Bacillus circulans WL $12^{37}$ was used as mycolytic strain. Pyricularia oryzae $\mathrm{P}_{2}$ was originally obtained from the Institute of Agricultural Sciences. Saccharomyces cerevisiae IAM 4307 was provided by the Institute of Applied Microbiology, University of Tokyo. Saccharomyces rouxxii IFO 0505, Hansenula anomala IFO 0122, H. ciferrii IFO 0905, Debaryomycess hansenii (membranaefaciens) IFO 0094, Schizosaccharomyces pombe IFO 0363 and Candida parapsilosis IFO 1022 were obtained from the Institute for Fermentation, Osaka.
Media for cultivation. Media for maintenance of B. circulans WL 12 and $P$. oryzae $\mathrm{P}_{2}$ and the method of cultivation of $P$. oryzae $\mathrm{P}_{2}$ for the preparation of the cell walls were the same as described previously.4) Yeast cells were grown on a YM medium ${ }^{53}$ containing (per liter) yeast extract, $3 \mathrm{~g}$; malt extract, $3 \mathrm{~g}$; peptone, $5 \mathrm{~g}$ and glucose, $10 \mathrm{~g}$ (50 g for Schizosacch. pombe). The medium for the enzyme production contained "Yeast Nitrogen Base" (Difco) supplemented with $12.6 \mathrm{~g}$ of monobasic potassium phosphate and $20 \mathrm{~g}$ of lyophilized yeast cells per liter, and the $\mathrm{pH}$ was adjusted to 7.0 before autoclaving.

Enzyme assays. Assays of $\beta-1,3, \beta-1,6$ glucanases and the lytic activity against the cell walls of $P$. oryzae $P_{2}$ were performed as described previously. ${ }^{1,4)}$

Preparation of the crude enzymes. Cells of $B$. circulans WL 12 were allowed to grow at $28^{\circ} \mathrm{C}$ for $72 \mathrm{hr}$ in the medium containing the inducer yeast cells as described above. After centrifugation to remove cells and debris, the supernatant fluid was concentrated to about $1 / 5$ of the volume in a rotary vacuum evaporator. The concentrated fluid was dialyzed against $0.05 \mathrm{M}$ phosphate buffer, $\mathrm{pH} 6.8$, and centrifuged. Ammonium sulfate was added to achieve $80 \%$ saturation. The precipitate was dissolved in $0.1 \mathrm{M}$ succinate buffer, $\mathrm{pH} 6.0$, and dialyzed overnight against $0.05 \mathrm{~m}$ succinate buffer, $\mathrm{pH} 6.0$.

Isoelectric focusing. Activity profiles of the crude enzymes were obtained with Ampholine Electrofocusing Equipment (LKB 8100-10, LKB-Produkter AB, Sweden) by the method described in the LKB instruction manual. Sucrose density gradient $(5 \sim 50 \%)$ was established by means of an Ampholine Gradient Mixer 
(LKB 8121). One-per cent carrier ampholyte was used. The sample was layered in the middle part of the column during the formation of the sucrose gradient, and isoelectric focusing was conducted at 700 volts for $48 \mathrm{hr}$. The temperature was maintained at $4^{\circ} \mathrm{C}$.

Cell wall preparation. Cell walls of $P$. oryzae $\mathrm{P}_{2}$ and various yeasts were prepared with a Dyno Mill (Type KDL, Willy A Bachofen Manufacturing Engineers, Basel, Switzerland). Breakage of cells was observed under a phase contrast microscope, and conditions were chosen to achieve nearly complete breakage of cells by two passages of cell suspension. Cell walls were repeatedly washed by differential centrifugation until the preparation became almost free of cytoplasmic materials.

\section{RESULTS}

\section{Progress of enzyme production}

Hundred milliliters of the enzyme production medium containing $2 \%$ of lyophilized yeast cells as inducer substrate was placed in a $500 \mathrm{ml}$ Sakaguchi flask and autoclaved. Cells of $B$. circulans WL 12 grown on an AWY slant at $28^{\circ} \mathrm{C}$ for 2 days were suspended in $8 \mathrm{ml}$ of water, and $2 \mathrm{ml}$ of the suspension was inoculated to the autoclaved medium described above. The culture was incubated on a reciprocal shaker at $28^{\circ} \mathrm{C}$. At certain time intervals, samples were withdrawn and, after centifugation and dialysis, the enzymes were assayed.

Figure 1 indicates that there are striking differences in the level of enzyme production, depending on the species of yeasts used as inducer substrates. The maximum activity of $\beta-1,3$ glucanase was 230 units $/ \mathrm{ml}$ on $H$. anomala whereas it was only 14 units $/ \mathrm{ml}$ on $C$. parapsilosis. The maximum activity of $\beta-1,6$ glucanase was 320 units $/ \mathrm{ml}$ on $D$. hansenii and 17 units $/ \mathrm{ml}$ on $C$. parapsilosis. When $H$. anomala cells were used as inducer, a very high level of $\beta-1,3$ glucanase was obtained whereas the level of $\beta-1,6$ glucanase was rather low. On $D$. hansenii cells, a very high level of $\beta-1,6$ glucanase and a fairly high level of $\beta-1,3$ glucanase were obtained.

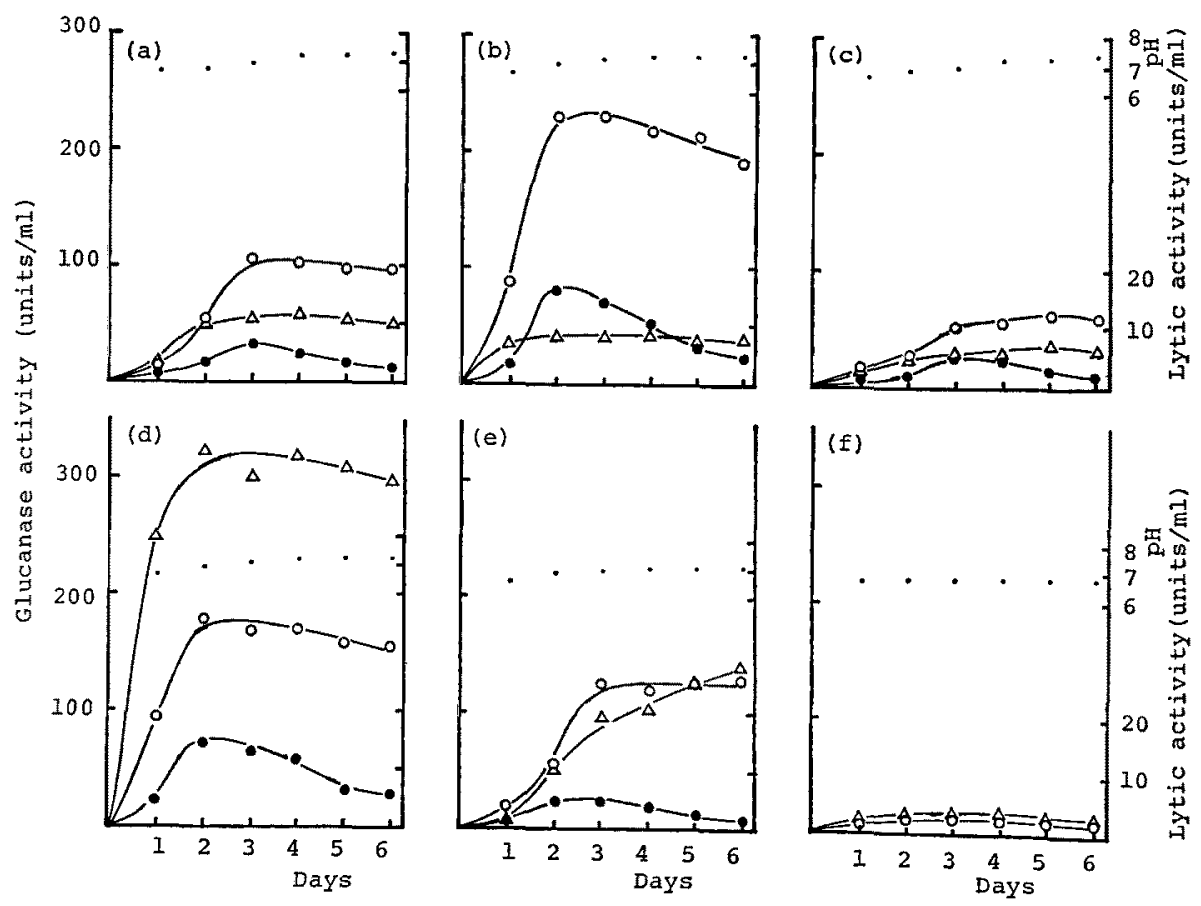

FIG. 1. Progress of Enzyme Production with Different Yeast Cells as Inducer Substrates.

(a) Sacch. rouxii, (b) H. anomala, (c) H. ciferrii, (d) D. hansenii, (e) Schizosacch. pombe, (f) C. parapsilosis.

$\bigcirc-0, \beta-1,3$ glucanase; $\triangle \longrightarrow \triangle, \beta-1,6$ glucanase; $-\bullet$ lytic activity; $\cdots, \mathrm{pH}$. 


\section{Isoelectric focusing}

Isoelectric focusing of the crude enzymes in a $\mathrm{pH}$ range of 4.0 to 8.0 was conducted as described in Materials and Methods. After electrophoretic fractionation, each fraction was dialyzed against $0.05 \mathrm{M}$ succinate buffer, $\mathrm{pH}$ 6.0. The volume of each fraction was determined, and the activity per $\mathrm{ml}$ was corrected to that before dialysis. For the assay of $\beta-1,3$ glucanase, $0.5 \mathrm{ml}$ of the sample and $0.5 \mathrm{ml}$ of $0.6 \%$ laminarin in $0.1 \mathrm{M}$ succinate buffer, $\mathrm{pH} 6.0$, were mixed. After incubation for $1 \mathrm{hr}$ at $38^{\circ} \mathrm{C}$, the reaction was stopped by adding $1 \mathrm{ml}$ of DNSA reagent. ${ }^{6}$. The mixture was heated in boiling water for $10 \mathrm{~min}$, and cooled with tap water. Eight mililiters of water was then added to the mixture, and its optical density at $540 \mathrm{~nm}$ was measured. For the assay of $\beta-1,6$ glucanase, $0.5 \mathrm{ml}$ of the sample and 0.5 $\mathrm{ml}$ of $0.6 \%$ lutean in $0.1 \mathrm{M}$ succinate buffer, $\mathrm{pH}$ 5.5 , were mixed. After incubation for $3 \mathrm{hr}$ at $38^{\circ} \mathrm{C}, 1 \mathrm{ml}$ of DNSA reagent was added, and the same procedure as described above was followed. For the lytic activity assay, $2 \mathrm{ml}$ of the sample and $1 \mathrm{ml}$ of the suspension of $0.3 \%$ of the cell walls of $P$. oryzae $\mathrm{P}_{2}$ in $0.05 \mathrm{M}$ phosphate buffer, $\mathrm{pH} 6.8$, were mixed and placed in an L-shaped tube, fitted to an incubator with a shaking device (Monoshin, Taiyo Kagakukogyo, Japan). After incubation for $3 \mathrm{hr}$ at $30^{\circ} \mathrm{C}$ under gentle shaking, the optical density at $660 \mathrm{~nm}$ was measured. The activity is expressed in terms of

$$
\frac{\mathrm{OD}_{0}-\mathrm{OD}_{3 \mathrm{hr}}}{\mathrm{OD}_{0}} \times 100
$$

As shown in Fig. 2, striking differences were observed among the isoelectric focusing patterns of the crude enzymes produced on different yeast cells as inducer substrates. Among the yeast strains tested, $D$. hansenii gave the most complex activity profiles (Fig. 2-e). For $\beta-1,3$ glucanases were observed three peaks at pI values of $6.8,5.8$ and 5.2 and one broad peak at $\mathrm{pI}$ around 4 with a shoulder in a more acidic range. Three peaks of $\beta-1,6$ glucanase at $\mathrm{pI}$ values of 8.0, 6.0 and 5.4 were present. On the other hand, the crude enzyme with $C$.


芯

Tube number $(3 \mathrm{ml} / \mathrm{tube})$

Fig. 2. Isoelectric Focusing of the Crude Enzymes Obtained with Various Yeast Cells as Inducer Substrates.

Inducer substrates: (a) Sacch.cerevisiae, (b) S. rouxii, (c) H. anomala, (d) H. ciferrii, (e) D. hansenii, (f) $C$. parapsilosis.

Total activities of $\beta-1,3$ and $\beta-1,6$ glucanases applied: (a) 2404 and 518, (b) 2102 and 1544, (c) 2947 and 469 , (d) 2014 and 469 , (e) 2412 and 1649 , (f) 171 and 300 .

$\bigcirc-0, \beta-1,3$ glucanase; $\triangle-\triangle, \beta-1,6$ glucanase;..--- , lytic activity, $\cdots . ., \mathrm{pH}$. 
parapsilosis cells as inducer substrate (Fig. 2-f) gave very simple patterns. Only one sharp peak of $\beta-1,3$ glucanase at pI 4.2 was observed. Two peaks of $\beta-1,6$ glucanase at $\mathrm{pI}$ values of 8.0 and 5.4 were present. In the case of the crude enzyme with $H$. ciferrii cells (Fig. 2-d) appeared one broad peak of $\beta-1,3$ glucanase at pI around 4 with a shoulder in more acidic range.

\section{Lysis of cell walls}

The culture fluids of $B$. circulans WL 12 grown on different yeast cells as described in MATERIALS AND METHODS were concentrated with a rotary vacuum evaporator and dialyzed overnight against $0.05 \mathrm{M}$ succinate buffer, pH 6.0. Activity of $\beta-1,3$ glucanase of each concentrate was adjusted to approximately 60 units $/ \mathrm{ml}$. To $1 \mathrm{ml}$ of this culture fluid was added $3 \mathrm{ml}$ of the cell wall suspension in $0.05 \mathrm{M}$ phosphate buffer containing $4 \mathrm{mg}$ of cell walls. Optical density at $660 \mathrm{~nm}$ was measured at certain time intervals, and $\mathrm{OD}_{\mathrm{t}} / \mathrm{OD}_{0} \times 100$ was

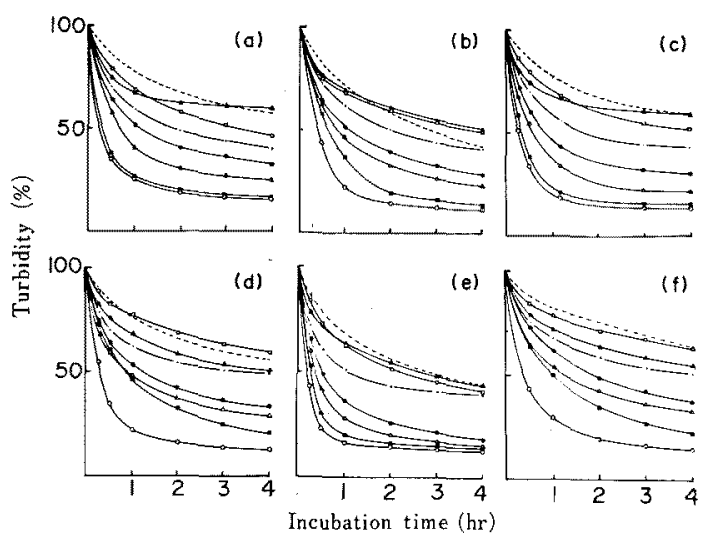

Frg. 3. Decomposition of the Cell Walls of Various Yeasts and $P$. oryzae $\mathrm{P}_{2}$ by the Actions of the Culture Fluids of $B$. circulans WL 12 Obtained with Cells of Various Yeasts as Inducer Substrates.

Inducer substrates: (a) Sacch. cerevisiae, (b) $S$. rouxii, (c) H. anomala, (d) $H$. ciferrii, (e) D. hansenii, (f) $C$. parapsilosis. Final activity $/ \mathrm{ml}$ of $\beta-1,3$ and $\beta-1,6$ glucanases: (a) 16.4 and 4.3 , (b) 13.6 and 10.4 , (c) 17.6 and 3.0 , (d) 15.2 and 9.3, (e) 14.9 and 18.6.

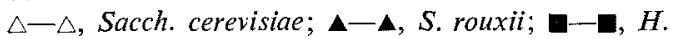
anomala; $\square-\square, H$. ciferrii; $-\bullet, D$. hansenii; ·- ·, Schizosacch. pombe; $\bigcirc-\mathrm{O}$, C. parapsilosis; --.--, $P$. oryzae $\mathrm{P}_{2}$. plotted against time. Figure 3 shows the lysis of cell walls of $P$. oryzae $\mathrm{P}_{2}$ and various yeasts with the culture filtrates of $B$. circulans WL 12 grown on different inducer substrates (yeast cells). In the culture fluid obtained with Sacch. cerevisiae cells, the cell walls of $C$. parapsilosis and $H$. anomala were digested very rapidly and extensively. The cell walls of other yeasts and $P$. oryzae $\mathrm{P}_{2}$ were digested at considerably different rates (Fig. 3-a). The cell walls of $C$. parapsilosis were decomposed most rapidly in any of the culture fluids used. Marked differences in the susceptibility of the cell walls (to decomposition) were observed among various yeasts and $P$. oryzae $\mathrm{P}_{\mathbf{2}}$, especially in the culture fluid obtained with $C$. parapsilosis cells (Fig. 3-f). In the culture fluid obtained with D. hansenii cells (Fig. 3-e), the cell walls of $D$. hansenii, Sacch. cerevisiae, $H$. anomala and $C$. parapsilosis were similar in susceptibility. Within $4 \mathrm{hr}$ of incubation the turbidity of the cell wall suspension of each of these 4 strains was reduced by more than $80 \%$. The turbidities of the cell wall suspensions of $P$. oryzae, $S$. rouxii, Schizosacch. pombe and $H$. ciferrii were reduced to about $50 \%$ of the original value within the same incubation period. Figure 4-a shows the change in turbidity of $D$. hansenii cell wall suspension by the actions of the culture fluids

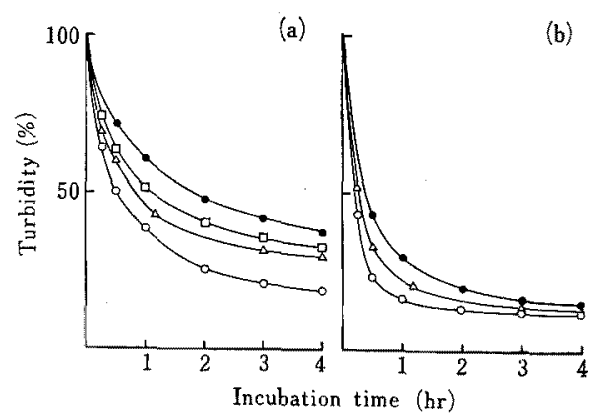

FIG. 4. Decomposition of the Cell Walls of $D$. hansenii (a) and C. parapsilosis (b) by the Actions of the Culture Fluids Produced by $B$. circulans WL 12 with Various Yeast Cells as Inducer Substrates. Symbols, inducer substrates and activity $/ \mathrm{ml}$ of $\beta-1,3$ and $\beta-1,6$ glucanases: $\triangle-\triangle, H$. anomala, 17.6 and $3 ; \square-\square, H$. ciferril, 15.2 and $9.3 ; \bigcirc-\bigcirc, D$. hansenii, 14.9 and $18.6 ;-0$, C. parapsilosis, 15.7 and 15.7. 
of which $\beta-1,3$ glucanase activity was adjusted to approximately 15 units $/ \mathrm{ml}$. Turbidity reduction was more rapid and extensive in the order of the complexity of the activity profiles of $\beta-1,3$ glucanases in isoelectric focusing (see Discussion). On the other hand, the same experiment with $C$. parapsilosis cell walls (Fig. 4-b) showed that the turbidity of the cell wall suspension was reduced at about the same rate and to about the same extent with any of the crude enzymes tested.

\section{DISCUSSION}

Bacillus circulans WL 12 produces several $\beta-1,3$ glucanases with different induction patterns according to the substrate glucans. ${ }^{2}$ We analyzed the activity profiles of $\beta-1,3$ glucanases of the crude enzymes produced in response to three different glucans, using a vertical polyacrylamide gel electrophoresis. Significant differences in the activity profiles of $\beta-1,3$ glucanases were observed among these preparations. The components of the $\beta-1,3$ glucanases were produced in different quantities, and exhibited characteristic activity profiles, very different from each other. We proposed the term "concerted induction of enzymes" for the concomitant production of similar enzymes [in the present case, either $\beta-1,3$ glucanases or $\beta-1,6$ glucanases upon induction with cell walls or with glucan of mixed linkages (e.g. $\beta-1,3$ and $\beta-1,6) .^{2 \prime} \quad$ Rombouts and Phaff ${ }^{7}$ also reported that the same strain, $B$. circulans WL 12, produced three $\beta-1,3$ glucanases (two lytic and one non-lytic) and two $\beta-1,6$ glucanases (lytic and non-lytic) upon induction with bakers' yeast cell walls or glucans. They found that lytic activity levels (against bakers' yeast cell walls) did not correlate with $\beta$-glucanase levels. Laminarin and pustulan induced negligible or no lytic activity. Pachyman induced moderate lytic activity, along with high $\beta-1,3$ glucanase and fairly high $\beta-1,6$ glucanase activities. Yeast glucan induced the highest lytic activity.

In the previous works ${ }^{1,2\rangle}$ we used a vertical polyacrylamide gel electrophoretic apparatus to compare the activity profiles of the $\beta-1,3$ glucanases. It was laborious and painstaking to slice gel and to extract enzymes. In the present study, we used isoelectric focusing to obtain activity profiles of the enzymes. Fairly reproducible results were obtained by this method, which made it much easier to compare many different enzyme systems. On account of the complexity of the enzyme mixtures, we are yet to obtain exact correspondences among the peaks obtained by the two methods.

In this work, we used the cells of six strains of yeasts as inducer substrates. Conspicuous differences were observed among the isoelectric focusing patterns of $\beta-1,3$ and $\beta-1,6$ glucanases. Owing to the heterogeneity of yeast glucans, their structural studies are very difficult. ${ }^{8 \sim 11}$ ) Major bonds so far reported are $\beta-1,3$ and $\beta-1,6$ glucopyranosyl linkages, but the extents of branching and distribution of these linkages are difficult to determine. We infer that the induction patterns of $\beta-1,3$ and $\beta-1,6$ glucanases of $B$. circulans WL 12 are, to a large extent, the reflection of the structures of the mixed linkage glucans $(\beta-1,3$ and $\beta-1,6)$. Structures of the glucans of $D$. hansenii cell walls are probably quite complex compared with other yeast strains tested and, on the other hand, those of $C$. parapsilosis may be rather simple.

Lyses of the cell walls of $P$. oryzae $\mathrm{P}_{2}$ and various yeasts by the culture fluids obtained with the cells of various yeasts as substrate inducers were compared. With any of the culture fluids, the rates of turbidity reduction of cell wall suspensions were considerably different, depending on the strain. Differences, in the rates and extents of turbidity reduction of the cell suspensions of various yeasts and $P$. oryzae $\mathrm{P}_{2}$, were particularly conspicuous with the culture fluid obtained with $C$. parapsilosis cells (Fig. 3-f). It is noteworthy that the isoelectric focusing patterns of $\beta$-glucanases of the crude enzyme system obtained from the above culture fluid were rather simple, showing only one peak of $\beta-1,3$ glucanase (Fig. 2-f). On the other hand, with the culture fluid obtained with $D$. hansenii cells as inducer substrate, the turbidities of the cell wall suspensions of four species of yeasts, namely, $D$. 
hansenii, Sacch. cerevisiae, $H$. anomala and C. parapsilosis were reduced very rapidly, and about $80 \%$ of the turbidity reduction occurred within $4 \mathrm{hr}$ of incubation (Fig. 3-e). The isoelectric focusing patterns of $\beta$-glucanases in this crude enzyme system were very complex (Fig. 2-e), and some synergistic effects are likely to be at work among the glucanases.

Lyses of $D$. hansenii cell walls by the crude enzyme systems produced with various yeast cells as substrate inducers were compared. With about the same $\beta-1,3$ glucanase activity (ca. 15 units $/ \mathrm{ml}$ ), the cell walls were most readily decomposed by the culture fluid enzyme produced with $D$. hansenii cells as inducer substrate. The rates of turbidity reduction of $D$. hansenii cell wall suspension were greater in the order of the culture fluids with $D$. hansenii, $H$. anomala, $H$. ciferrii and $C$. parapsilosis as inducers. It is noteworthy that the major $\beta-1,3$ glucanase peaks in the isoelectric focusing pattern of the crude enzyme induced with $D$. hansenii cells were observed at pIs 6.8 , 5.8, 5.2 and 4 (broad) (Fig. 2-e). The crude enzyme induced with $H$. anomala cells showed large peaks of $\beta-1,3$ glucanases at pIs 5.8 and 4 (broad) (Fig. 2-c). The crude enzyme induced with $H$. ciferrii cells showed one broad peak of $\beta-1,3$ glucanase at around $\mathrm{pI} 4$. In the case of the crude enzyme with $C$. parapsilosis cells, only one sharp peak of $\beta-1,3$ glucanase at pI 4.2 was observed (Fig. 2-f). Thus, with these culture fluids, the lysis of the cell walls of $D$. hansenii was stronger in the other of the complexity of the isoelectric focusing patterns of $\beta-1,3$ glucanases in the crude enzymes. The results again indicated that there were synergistic effects among $\beta$ glucanases for the lysis of cell walls of $D$. hansenii. On the other hand, the rates and extents of the lysis of $C$. parapsilosis cell walls changed little with the culture fluid.

Acknowledgement. This research was supported in part by a research grant from the Ministry of Education of Japan.

\section{REFERENCES}

1) Y. Kobayashi, H. Tanaka and N. Ogasawara, Agric. Biol. Chem., 38, 959 (1974).

2) H. Tanaka, Y. Kobayashi and N. Ogasawara, ibid., 38, 967 (1974).

3) H. Tanaka and H. J. Phaff, J. Bacteriol., 89, 1570 (1965).

4) H. Tanaka, N. Ogasawara, T. Nakajima and K. Tamari, J. Gen. Appl. Microbiol., 16, 39 (1970).

5) L. J. Wickerhan, Tech. Bull. No. 1029, U.S. Dept. Agric., Washington D. C., 1951.

6) J. R. Sumner and G. F. Sommer, "Laboratory Experiments in Biological Chemistry," Academic Press, New York, 1944, p. 3435.

7) M. Rombouts and H. J. Phaff, Eur. J. Biochem., 63, 109 (1976).

8) H. J. Phaff, "The Yeasts," Vol. 2, ed. by A. H. Rose and J. S. Harrison, Academic Press, London and New York, 1971, p. 135.

9) D. J. Manners, A. J. Masson and J. C. Patterson, Biochem. J., 135, 19 (1973).

10) D. J. Manners, A. J. Masson and J. C. Patterson, J. Gen. Microbiol., 80, 411 (1974).

11) H. Tanaka and H. J. Phaff, Symposium über Hefe-Protoplasten, Akademie-Verlag, Berlin,1967, p. 112 . 